Article

\title{
Glass-Ceramic Sealants for SOEC: Thermal Characterization and Electrical Resistivity in Dual Atmosphere
}

\author{
Hassan Javed ${ }^{1, *}$, Antonio Gianfranco Sabato ${ }^{2}$, Mohsen Mansourkiaei ${ }^{3}$, Domenico Ferrero ${ }^{3}$ (i), \\ Massimo Santarelli ${ }^{3}$, Kai Herbrig ${ }^{1}$, Christian Walter ${ }^{1}$ and Federico Smeacetto ${ }^{4}$ \\ 1 Sunfire GmbH, Gasanstaltstraße 2, 01237 Dresden, Germany; kai.herbrig@sunfire.de (K.H.); \\ christian.walter@sunfire.de (C.W.) \\ 2 IREC-Institut de Recerca en Energia de Catalunya, 08930 Sant Adrià de Besòs, Barcelona, Spain; \\ gsabato@irec.cat \\ 3 Department of Energy (DENERG), Politecnico di Torino, 10129 Turin, Italy; \\ mohsen.mansourkiaei@polito.it (M.M.); domenico.ferrero@polito.it (D.F.); \\ massimo.santarelli@polito.it (M.S.) \\ 4 Department of Applied Science and Technology (DISAT), Politecnico di Torino, 10129 Turin, Italy; \\ federico.smeacetto@polito.it \\ * Correspondence: hassan.javed@sunfire.de
}

Received: 10 June 2020; Accepted: 16 July 2020; Published: 17 July 2020

\begin{abstract}
A Ba-based glass-ceramic sealant is designed and tested for solid oxide electrolysis cell (SOEC) applications. A suitable $\mathrm{SiO}_{2} / \mathrm{BaO}$ ratio is chosen in order to obtain $\mathrm{BaSi}_{2} \mathrm{O}_{5}$ crystalline phase and subsequently favorable thermo-mechanical properties of the glass-ceramic sealant. The glass is analyzed in terms of thermal, thermo-mechanical, chemical, and electrical behavior. Crofer22APU-sealant-Crofer22APU joined samples are tested for $2000 \mathrm{~h}$ at $850^{\circ} \mathrm{C}$ in a dual atmosphere test rig having reducing atmosphere of $\mathrm{H}_{2}: \mathrm{H}_{2} \mathrm{O} 50 / 50(\mathrm{~mol} \%)$ and under the applied voltage of $1.6 \mathrm{~V}$. In order to simulate the SOEC dynamic working conditions, thermal cycles are performed during the long-term electrical resistivity test. The glass-ceramic shows promising behavior in terms of high density, suitable CTE, and stable electrical resistivity $\left(10^{6}-10^{7} \Omega \mathrm{cm}\right)$ under SOEC conditions. The SEM-EDS post mortem analysis confirms excellent chemical and thermo-mechanical compatibility of the glass-ceramic with Crofer22APU.
\end{abstract}

Keywords: SOEC; sealants; glass-ceramic; joining

\section{Introduction}

The high temperature solid oxide electrolysis cell (SOEC) technology is considered as one of the most attractive method to produce green hydrogen because of its high efficiency [1-5]. In order to maximize the efficiency, the role of sealants is crucial in planar SOEC stack configuration. Sealants are employed with the aim to avoid any gas leakage and to bond metallic interconnect with the zirconia-based electrolyte. The operating conditions of an SOEC stack such as high working temperature of $700-1000{ }^{\circ} \mathrm{C}$, presence of oxidizing and reducing atmospheres, expected lifetime of more than $40,000 \mathrm{~h}$, and applied thermal cycles during operation, make the synthesis of suitable sealants quite challenging [6-8].

Glass-ceramics are considered to be the most promising sealant candidates owing to their high electrical resistivity, thermal and chemical stability at high working temperature, and due to the possibility to tune their physical and chemical properties (i.e., viscosity, coefficient of thermal expansion) by tailoring their composition [9-12]. In the past, various glass compositions have been 
designed and tested mainly for solid oxide fuel cell (SOFC). Although, most of the requirements for an SOEC sealant are similar to that of SOFC, however, in SOEC the sealant has to be electrically insulator under the applied voltage which is typically $1.3 \mathrm{~V}$ higher than in SOFC [8,13-15].

According to literature, silica is most commonly used as a main glass former. Besides that, different alkali and alkaline earth metals are used as modifiers to tune the properties of the resultant glass-ceramic [16-20]. The choice and relative concentration of modifiers is the most important factor in order to control the overall properties of glass-ceramic sealants. Alkali oxide-based glass-ceramic sealants are usually not very attractive because of their low electrical resistivity and detrimental reaction with $\mathrm{Cr}$ at high temperature and under applied voltage [21,22]. Among alkaline earth metal oxides, $\mathrm{BaO}$ is the most extensively used modifier as it improves the coefficient of thermal expansion (CTE) and wettability of the glass-ceramic sealant [6,23-27]. However, BaO-based glasses mostly suffer from the formation of high $\mathrm{CTE} \mathrm{BaCrO}_{4}$ phase because of chemical reaction between $\mathrm{Ba}$ (from glass) and $\mathrm{Cr}$ (from the interconnect). The high CTE phase having CTE in the range of $20-22 \times 10^{-6} \mathrm{~K}^{-1}$, often resulted in stress generation and consequently delamination at interconnect/sealant interface [28,29]. For instance; a $\mathrm{SiO}_{2}-\mathrm{B}_{2} \mathrm{O}_{3}-\mathrm{BaO}$-based glass system investigated by Peng et al. [29] showed strong adhesion with SS410 interface and 8YSZ ( $8 \mathrm{~mol} \%$ Yttria-stabilized Zirconia) electrolyte after joining with no undesirable phase formation. However, under the thermal cycling performed at $700{ }^{\circ} \mathrm{C}$, a gas leakage was detected. SEM-EDS post mortem analyses confirmed that the formation of undesirable phase $\mathrm{BaCrO}_{4}$ took place at glass-ceramic/interconnect interface.

$\mathrm{SiO}_{2}$ - $\mathrm{BaO}-\mathrm{CaO}-\mathrm{Al}_{2} \mathrm{O}_{3}$-based glass systems developed by Gosh et al. [30], also showed good chemical stability and high electrical resistivity. However, the electrical resistivity was measured on glass-ceramic pellets at $800{ }^{\circ} \mathrm{C}$ up to only $100 \mathrm{~h}$ of steady operation. Similarly, Rost et al. [13] also investigated the electrical resistivity of different $\mathrm{BaO}$-based glass systems in dual atmosphere at $850{ }^{\circ} \mathrm{C}$ up to $500 \mathrm{~h}$. However, no information was reported about the long-term testing $(>1000 \mathrm{~h})$ and performance during thermal cycles. Schilm et al. [31] also designed different glass compositions from $\mathrm{SiO}_{2}-\mathrm{BaO}-\mathrm{CaO}-\mathrm{Al}_{2} \mathrm{O}_{3}$ system and their electrical resistivity was measured in dual atmosphere for $300 \mathrm{~h}$ under the applied voltage of $0.7 \mathrm{~V}$ and $1.3 \mathrm{~V}$. The compatibility of glasses was studied with CFY (Cr-Fe-Y) interconnect and found that a suitable $\mathrm{BaO} / \mathrm{SiO}_{2}$ is important in order to minimize the formation of $\mathrm{BaCrO}_{4}$ phase.

In this study, a Ba-based glass-ceramic sealant was designed and studied under SOEC conditions. Besides thermal, chemical, and thermo-mechanical analysis, the electrical resistivity of joined samples was analyzed at $850{ }^{\circ} \mathrm{C}$ up to $2000 \mathrm{~h}$ in dual $\left(\mathrm{H}_{2} \mathrm{O}-\mathrm{H}_{2}\right.$ and air) atmosphere. Thermal cycles were also applied during resistivity analysis in order to simulate the dynamic SOEC conditions.

\section{Experimental}

The composition ( $\mathrm{mol} \%$ ) of the glass system (further labelled as HJ28) is shown in Table 1. The glass system has $\mathrm{SiO}_{2}$ as glass former, while $\mathrm{BaO}$ as a main glass modifier. According to $\mathrm{SiO}_{2}-\mathrm{BaO}$ binary phase diagram, the $\mathrm{SiO}_{2} /\left(\mathrm{SiO}_{2}+\mathrm{BaO}\right)$ of 0.67 is required to obtain a $\mathrm{BaSi}_{2} \mathrm{O}_{5}$ phase [32]. The $\mathrm{BaSi}_{2} \mathrm{O}_{5}$ phase has a CTE of 12-14 $\times 10^{-6} \mathrm{~K}^{-1}$ [33], therefore, is beneficial to obtain a glass-ceramic sealant with a suitable CTE for SOEC applications. Nevertheless, the presence of high concentration of $\mathrm{Ba}$, can also lead to the formation of high CTE $\mathrm{BaCrO}_{4}$ phase. In $\mathrm{HJ} 28$ glass system, a $\mathrm{SiO}_{2} /\left(\mathrm{SiO}_{2}+\mathrm{BaO}\right)$ of 0.73 was chosen in order to form high $\mathrm{CTE} \mathrm{BaSi}_{2} \mathrm{O}_{5}$ phase and to avoid the formation of $\mathrm{BaCrO}_{4}$ phase. Besides that, $\mathrm{CaO}, \mathrm{B}_{2} \mathrm{O}_{3}$, and $\mathrm{Y}_{2} \mathrm{O}_{3}$ were added in order to adjust the viscosity and the $\mathrm{CTE}$ of the sealant.

Table 1. Composition (mol\%) of HJ28 glass system.

\begin{tabular}{cccccc}
\hline $\mathrm{SiO}_{2}$ & $\mathrm{BaO}$ & $\mathrm{CaO}$ & $\mathbf{B}_{\mathbf{2}} \mathrm{O}_{\mathbf{3}}$ & $\mathrm{Al}_{\mathbf{2}} \mathrm{O}_{3}$ & $\mathrm{Y}_{2} \mathrm{O}_{\mathbf{3}}$ \\
\hline 60.00 & 22.00 & 6.35 & 7.65 & 3.00 & 1.00 \\
\hline
\end{tabular}


For glass synthesis, different precursor powders were thoroughly mixed for $24 \mathrm{~h}$ and subsequently melted at $1600{ }^{\circ} \mathrm{C}$ for one hour in a Rh-Pt crucible. The molten glass was then air quenched on a brass plate followed by ball milling and sieving to obtain glass particles $<25 \mu \mathrm{m}$. The glass transition (Tg) and crystallization temperature of as-casted glass were measured using differential thermal analysis (DTA Netzsch, Eos, Selb, Germany), while the sintering behavior was analyzed by heating stage microscope (HSM, Hesse Instruments, Osterode am Harz, Germany) at a heating rate of $5^{\circ} \mathrm{C} / \mathrm{min}$. The coefficient of thermal expansion of as-casted glass and as-joined glass-ceramic was measured by dilatometer (Netzsch, DIL 402 PC/4). The details about the joining parameters of glass-ceramic will be discussed in the next sections of this article. For each characterization method, at least three measurements were carried out in order to ensure the reproducibility of data.

For phase analysis, the XRD (PanAlytical X'Pert Pro PW 3040/60 Philips (The Netherlands)) was performed on glass-ceramic with $\mathrm{Cu} \mathrm{K} \alpha$ and the X'Pert software. In order to investigate the compatibility of HJ28 glass-ceramic with the Crofer22APU (from VDM ${ }^{\circledR}$ Metals) interconnect and 3YSZ electrolyte, the Crofer/glass/3YSZ joint was processed in static air in a carbolite furnace (CWF 13/5). For this purpose, the slurry composed of glass particles and ethanol (70:30 wt $\%$ ) was manually deposited on the Crofer22APU and 3YSZ substrates. The SEM-EDS analysis was carried out to understand the compatibility and adhesion of glass-ceramic with Crofer22APU interconnect and 3YSZ electrolyte, and to analyze the glass-ceramic microstructure.

The electrical resistivity of the Crofer22APU/glass-ceramic/Crofer22APU joint was measured in-situ at $850{ }^{\circ} \mathrm{C}$, under dual atmosphere and applied voltage. The glass was deposited in form of slurry on a cleaned plate of Crofer22APU $(3 \mathrm{~cm} \times 6 \mathrm{~cm} \times 0.2 \mathrm{~cm})$ to form a closed sealing frame Figure 1a) and joined to a second Crofer22APU plate of the same size. The lower plate has two holes to allow the inlet and outlet of a controlled reducing atmosphere during the experiment, while the external side of the glass sealing was exposed to static air (Figure 1b). Thermiculite ${ }^{\mathrm{TM}} 866$ (Flexitallic, Ticengo, Italy) sealing gaskets were employed to ensure gas tightness between the lower plate of joined sample and the gas distribution/collection fixture in the furnace. A mixture of $50 \mathrm{~mol} \%$ hydrogen and $50 \mathrm{~mol} \%$ steam was sent to the joint sample during the experiment. Uniformly distributed weight was put on the top plate to facilitate the sintering and the adhesion of the sealant. The joining treatment described in Section 3.1 was applied before settling the temperature to $850^{\circ} \mathrm{C}$ and exposing the sample to the dual atmosphere. A voltage of $1.6 \mathrm{~V}$ was applied between upper and lower plates, connected to a voltage generator and a measuring circuit Figure $1 \mathrm{~b}$ by platinum wires point welded on each plate. Gas flow measurement at the reducing atmosphere outlet was periodically performed during the test to verify the sealing integrity between test fixture and lower plate and of the joint sample.

The resistivity of the joint sample- $R_{S}$ - was indirectly evaluated by measuring the voltage drop $-V_{m}$-on a known resistance $R_{m}$ that was put in an electrical circuit in series with the Crofer22APU/glass-ceramic/Crofer22APU (see Figure 1b). The voltage generator was regulated during the experiment in order to have a voltage of $1.6 \mathrm{~V}$ on the sample, i.e., the sum of $\mathrm{V}$ and $\mathrm{V}_{\mathrm{m}}$ was maintained equal to $1.6 \mathrm{~V}$. By solving the circuit, the resistance $R_{S}$ is calculated as: $R_{S}=R_{m}\left(V-V_{m}\right) / V_{m}$, and consequently the resistivity is derived from the geometry (area and thickness) of the sealing frame.

In order to simulate the real working conditions of SOEC, three thermal cycles were performed after $500 \mathrm{~h}$ of resistivity test, in which the Crofer22APU/HJ28 glass-ceramic/Crofer22APU-joined sample was cooled down from $850{ }^{\circ} \mathrm{C}$ to room temperature at $2{ }^{\circ} \mathrm{C} / \mathrm{min}$.

After the electrical resistivity test, the SEM-EDS post mortem analysis was carried out to observe the microstructure, porosity in addition to chemical and thermo-mechanical compatibility of HJ28 glass-ceramic sealant with Crofer22APU. 
(a)



(b)

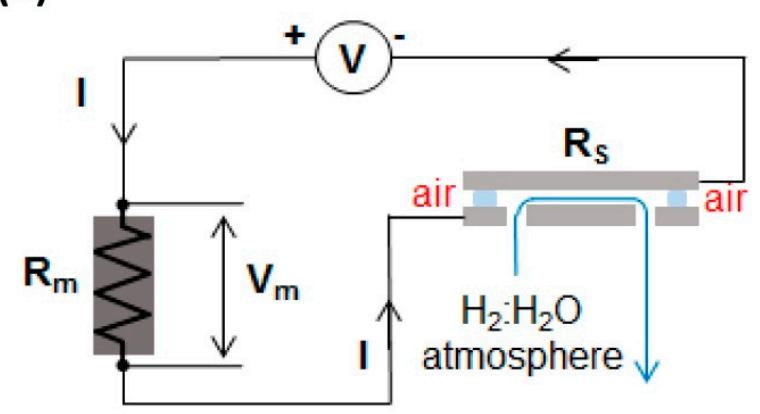

Figure 1. (a) Schematic of sample and (b) measuring setup, for the electrical resistivity analysis in dual atmosphere.

\section{Results and Discussion}

\subsection{Thermal Analysis}

The DTA and HSM curves for the HJ28 as-casted glass are shown in Figure 2. The glass transition $\left(T_{\mathrm{g}}\right)$ and peak crystallization temperature $\left(T_{\mathrm{p}}\right)$ obtained from DTA, as well as the first sintering temperature $\left(T_{\mathrm{FS}}\right)$ and maximum sintering temperature $\left(T_{\mathrm{MS}}\right)$ obtained from HSM analyses are given in Table 2.

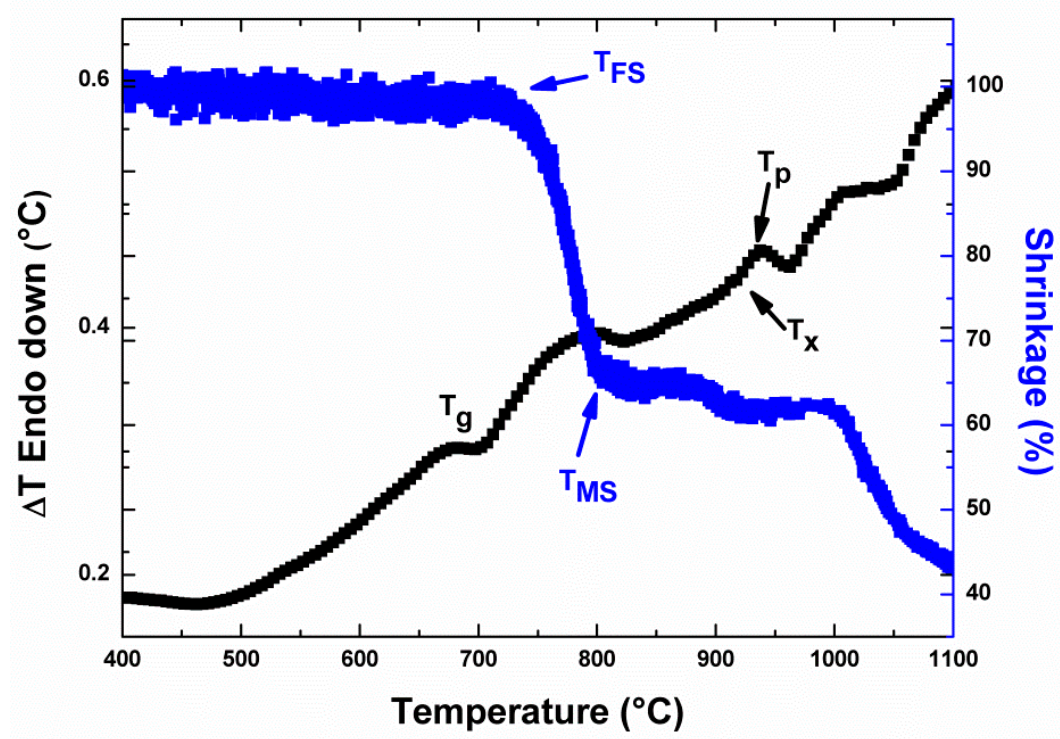

Figure 2. Differential thermal analysis (DTA) and heating stage microscope (HSM) curves of HJ28 as-casted glass. Analyses were carried out at $5^{\circ} \mathrm{C} / \mathrm{min}$. 
Table 2. Characteristic temperatures and coefficient of thermal expansion (CTE) of HJ28 glass system, obtained from DTA, HSM, and dilatometer.

\begin{tabular}{cc}
\hline Glass transition temperature $T_{\mathrm{g}}\left({ }^{\circ} \mathrm{C}\right)$ & $685 \pm 2$ \\
\hline Onset of crystallization $\left({ }^{\circ} \mathrm{C}\right)$ & $907 \pm 2$ \\
\hline Peak crystallization temperature $T_{\mathrm{p}}\left({ }^{\circ} \mathrm{C}\right)$ & $930 \pm 3$ \\
\hline First shrinkage temperature $T_{\mathrm{FS}}\left({ }^{\circ} \mathrm{C}\right)$ & $717 \pm 2$ \\
\hline Maximum shrinkage temperature $T_{\mathrm{MS}}\left({ }^{\circ} \mathrm{C}\right)$ & $829 \pm 1$ \\
\hline $\begin{array}{c}\mathrm{CTE} \text { of as-cast glass } / 1 \times 10^{-6} \mathrm{~K}^{-1} \\
\left(200{ }^{\circ} \mathrm{C}-500^{\circ} \mathrm{C}\right)\end{array}$ & $8.5 \pm 0.1$ \\
\hline \begin{tabular}{c}
$\left(200{ }^{\circ} \mathrm{C}-500{ }^{\circ} \mathrm{C}\right)$ \\
\hline
\end{tabular}
\end{tabular}

The DTA analysis of the HJ28 glass (Figure 2) showed that the as-casted glass has $T_{\mathrm{g}}$ of $685^{\circ} \mathrm{C}$. A low intensity exothermal peak can be seen around $930^{\circ} \mathrm{C}$, labelled as $T_{\mathrm{p}}$. The absence of sharp crystallization peak during DTA analysis of glass has been observed in our previous studies [8], and is most likely due to the fact that the degree of devitrification in the HJ28 glass is not significant to be detected. On the other hand, the HSM analysis of HJ28 (Figure 2 and Table 2) showed that the sintering process started at $717^{\circ} \mathrm{C}$, while the maximum sintering was obtained at $829^{\circ} \mathrm{C}$. After the completion of sintering process, the $\mathrm{HJ} 28$ glass showed a viscous flow that resulted in slightly further shrinkage.

In order to obtain a dense sealant, the sintering should be complete before the start of crystallization phenomena, otherwise, the increased viscosity due to crystallization can lead to the formation of residual pores within the glass-ceramic [18]. From the Figure 2 and characteristic temperatures mentioned in the Table 2, it is clear that the sintering process of the HJ28 glass system completed prior to the crystallization.

In order to synthesize the $\mathrm{HJ} 28$ glass-ceramic, a heat treatment of $950{ }^{\circ} \mathrm{C}$ having dwell time of $2 \mathrm{~h}$, was chosen. The selection of heat treatment was based on the crystallization and sintering data obtained from the DTA and HSM analyses, and was chosen to obtain a maximum densification and sufficient crystallization within the resultant glass-ceramic. For glass-ceramic synthesis, the heating/cooling rate of $2{ }^{\circ} \mathrm{C} / \mathrm{min}$ was used in order to minimize the possibilities of stress generation due to fast heating/cooling rates.

The CTEs of as-casted glass and as-joined glass-ceramic are also reported in Table 2. The as-casted $\mathrm{HJ} 28$ glass and as-joined glass-ceramic showed the CTEs of $8.5 \times 10^{-6} \mathrm{~K}^{-1}$ and $9.4 \times 10^{-6} \mathrm{~K}^{-1}$ respectively, in the temperature range of $200-500{ }^{\circ} \mathrm{C}$. The increase in the CTE of glass-ceramic as compared with the parent glass is due to the formation of high CTE crystalline phases. Further details about the crystalline phases will be discussed in the later sections of this article. Nevertheless, the CTE of $\mathrm{HJ} 28$ glass-ceramic is matching with CTEs of other cell components i.e., Crofer22APU $\left(12 \times 10^{-6} \mathrm{~K}^{-1}\right)$ and 3 YSZ $\left(10.5 \times 10^{-6} \mathrm{~K}^{-1}\right),[7,31]$ and is suitable for the SOEC applications.

\subsection{XRD and Microstructural Analysis}

The XRD pattern of the as-joined HJ28 glass-ceramic is shown in Figure 3. According to the XRD analysis, the as-joined $\mathrm{HJ} 28$ glass-ceramic contains only $\mathrm{BaSi}_{2} \mathrm{O}_{5}$ crystalline phase. The reference pattern of $\mathrm{BaSi}_{2} \mathrm{O}_{5}$ (PDF card \# 00-026-0176) is also shown in Figure 3. The $\mathrm{BaSi}_{2} \mathrm{O}_{5}$ phase has CTE in the range of $12-14 \times 10^{-6} \mathrm{~K}^{-1}$ [33] and is important to obtain a high CTE $\left(9-12 \times 10^{-6} \mathrm{~K}^{-1}\right)$ glass-ceramic sealant, for the SOEC applications [7]. These XRD results also validate the rationale behind designing the $\mathrm{HJ} 28$ glass composition, i.e., to have a high CTE $\mathrm{BaSi}_{2} \mathrm{O}_{5}$ phase and to avoid the formation of cristobalite $\left(\mathrm{SiO}_{2}\right)$ phase. Moreover, the XRD analyses are also in agreement with the dilatometer results, indicating that the formation of high $\mathrm{CTE} \mathrm{BaSi}_{2} \mathrm{O}_{5}$ is responsible for the increase in CTE of HJ28 glass-ceramic as compared with as-casted glass. 


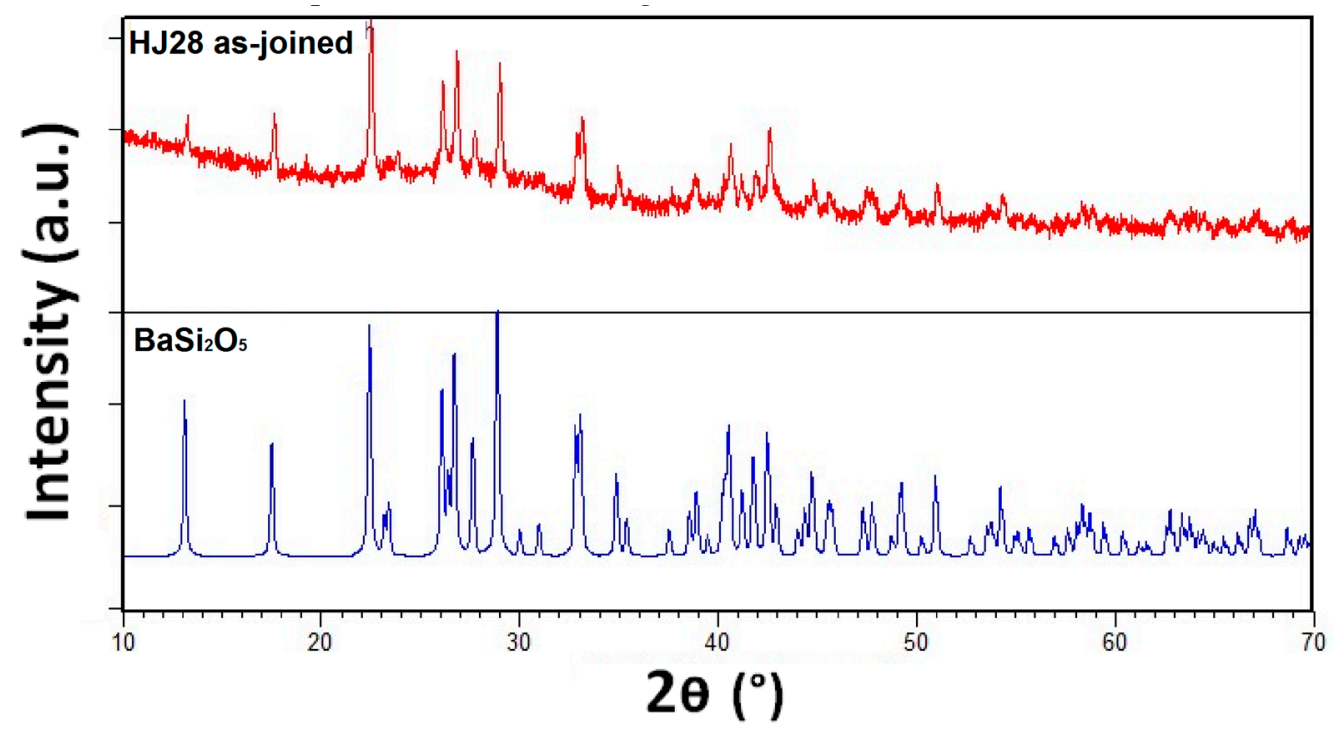

Figure 3. XRD pattern of $\mathrm{HJ} 28$ glass-ceramic synthesized at $950{ }^{\circ} \mathrm{C}$ for $2 \mathrm{~h}$ at heating rate of $2{ }^{\circ} \mathrm{C} / \mathrm{min}$.

The compatibility and bonding of the HJ28 glass-ceramic with the Crofer22APU interconnect and 3YSZ electrolyte were investigated by producing the Crofer22APU/glass-ceramic/3YSZ joined samples according to the heat treatments mentioned above. The SEM image of the Crofer22APU/HJ28 glass-ceramic/3YSZ joint cross section is shown in Figure 4. The HJ28 glass-ceramic showed good interfacial bonding with the Crofer22APU and 3YSZ substrates, with no crack or delamination at either interface. Some isolate pores can be seen in the as-joined glass-ceramics; however, these pores are not interconnected and could be formed as a result of manual glass deposition. Moreover, no crack within the as-joined glass-ceramics was observed.

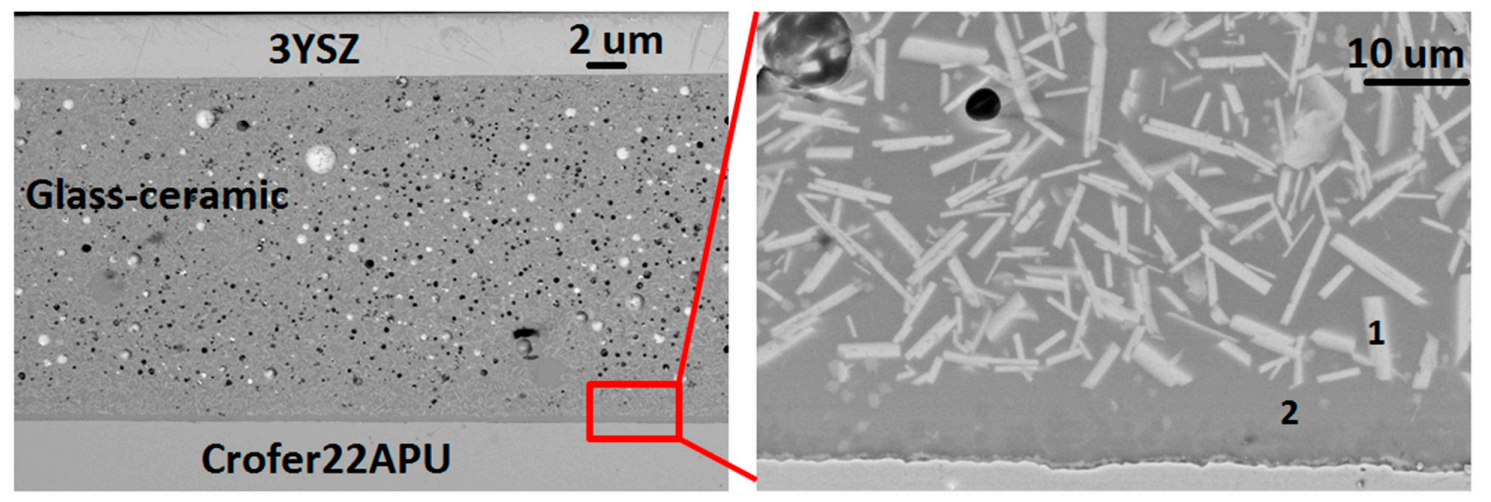

Figure 4. SEM images of as-joined Crofer22APU/HJ28/3YSZ joined samples.

The microstructure of the HJ28 glass-ceramic after joining is quite homogenous. The crystalline phases are uniformly distributed throughout the joining area. The EDS analysis reported in Table 3 confirmed that the bright phase (point 1 ) in the $\mathrm{HJ} 28$ as-joined glass-ceramic is the $\mathrm{BaSi}_{2} \mathrm{O}_{5}$ phase, while the dark phase (phase 2 ) is the residual glassy phase. The presence of $10 \mathrm{wt} \%$ of $\mathrm{Ba}$ and $3.7 \mathrm{wt} \%$ of Ca into the residual glassy phase is beneficial to maintain the CTE and viscosity of residual glass. The SEM-EDS analyses performed on the as-joined HJ28 glass-ceramics are in agreement with the XRD results. 
Table 3. EDS point analyses (at. \%) performed on the HJ28 glass-ceramics as shown in Figure 4.

\begin{tabular}{ccc}
\hline Elements & Point $\mathbf{1}$ & Point $\mathbf{2}$ \\
\hline O & 48.0 & 49.7 \\
Si & 35.2 & 31.6 \\
Ba & 15.1 & 10.1 \\
Ca & 1.7 & 3.7 \\
Al & - & 4.3 \\
Y & - & 0.6 \\
\hline
\end{tabular}

\subsection{Electrical Characterization in Dual Atmosphere and Post Mortem Analysis}

Figure 5 shows the electrical resistivity curve for the Crofer22APU/HJ28 glass-ceramic/ Crofer22APU joined sample, as measured at $850^{\circ} \mathrm{C}, 1.6 \mathrm{~V}$ and under dual atmosphere. The electrical resistivity for the Crofer22APU/HJ28 glass-ceramic/Crofer22APU joined sample was recorded in the range of $10^{6}-10^{7} \Omega \mathrm{cm}$ thus higher than the minimum threshold $\left(10^{4} \Omega \mathrm{cm}\right)$ required to ensure an insulation between the two conducting Crofer22APU plates [34]. The electrical resistivity curve is uniform with small fluctuations. After $500 \mathrm{~h}$, a significant increase in the electrical resistivity is due to the applied thermal cycles. Resistivity peaks occurred during cooling down phases of thermal cycles, as expected from the higher glass-ceramic resistivity at lower temperature. However, after the thermal cycles the resistivity achieved the same values as prior to the thermal cycles. The smooth and uniform resistivity curve demonstrates very good insulating characteristics of the glass-ceramic sealant. Furthermore, these values also suggest that neither corrosion phenomena nor any chemical interaction took place between the HJ28 sealant and the Crofer22APU interconnects.

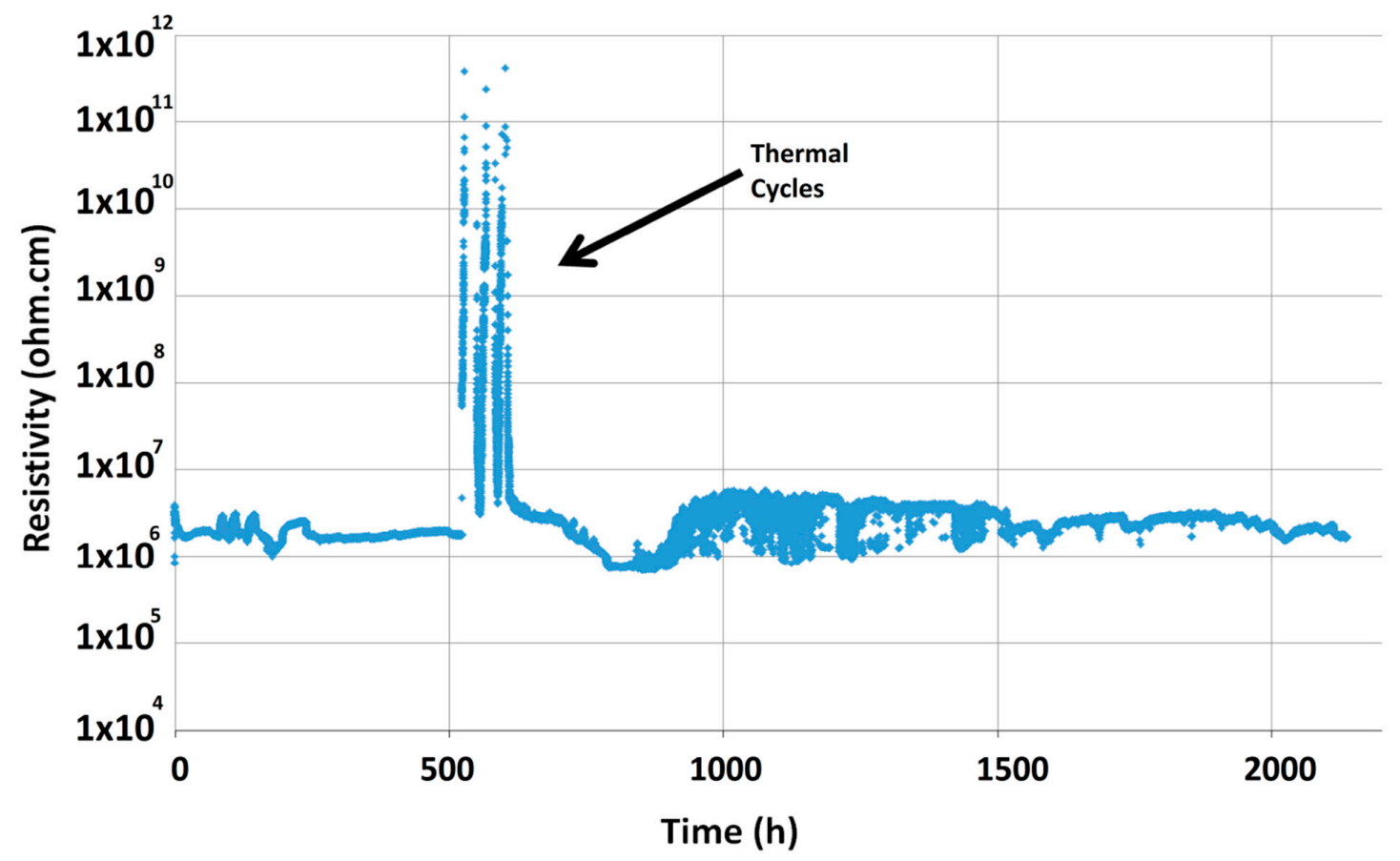

Figure 5. Electrical resistivity of Crofer22APU/HJ28 glass-ceramic/Crofer22APU joined sample, as measured for $2000 \mathrm{~h}$ at $850^{\circ} \mathrm{C}$ under the applied voltage of $1.6 \mathrm{~V}$.

Figure 6 shows the SEM-EDS post mortem analysis carried out at cathodic polarized Crofer22APU/HJ28 glass-ceramic interface at the air side after the long-term electrical resistivity test in dual atmosphere. The glass-ceramic seems to be highly dense with negligible amount of closed porosity. The formation of porosity is most likely due to the manual deposition of the glass. The glass-ceramic shows good adhesion with the cathodic polarized Crofer22APU substrate. From the 
EDS-mapping shown in Figure 6, the presence of $\mathrm{Cr}$ rich region can be seen at glass-ceramic/air interface. These $\mathrm{Cr}$ containing phase corresponds to $\mathrm{BaCrO}_{4}$, which was formed most likely because of the chemical reaction between the Ba from glass-ceramic and $\mathrm{Cr}$ from Crofer22APU. The formation of high CTE $\mathrm{BaCrO}_{4}$ is commonly observed in most of the Ba-based glass, and can lead to delamination at Crofer22APU/glass-ceramic interface $[25,28,29,35,36]$. However, in case of HJ28 glass-ceramic, the chromates were only limited along the air side and no chromates were formed at HJ28 glass-ceramic/Crofer22APU interface, thus ensured strong bonding. This effect was due to excellent adhesion of the sealant to the Crofer22APU.

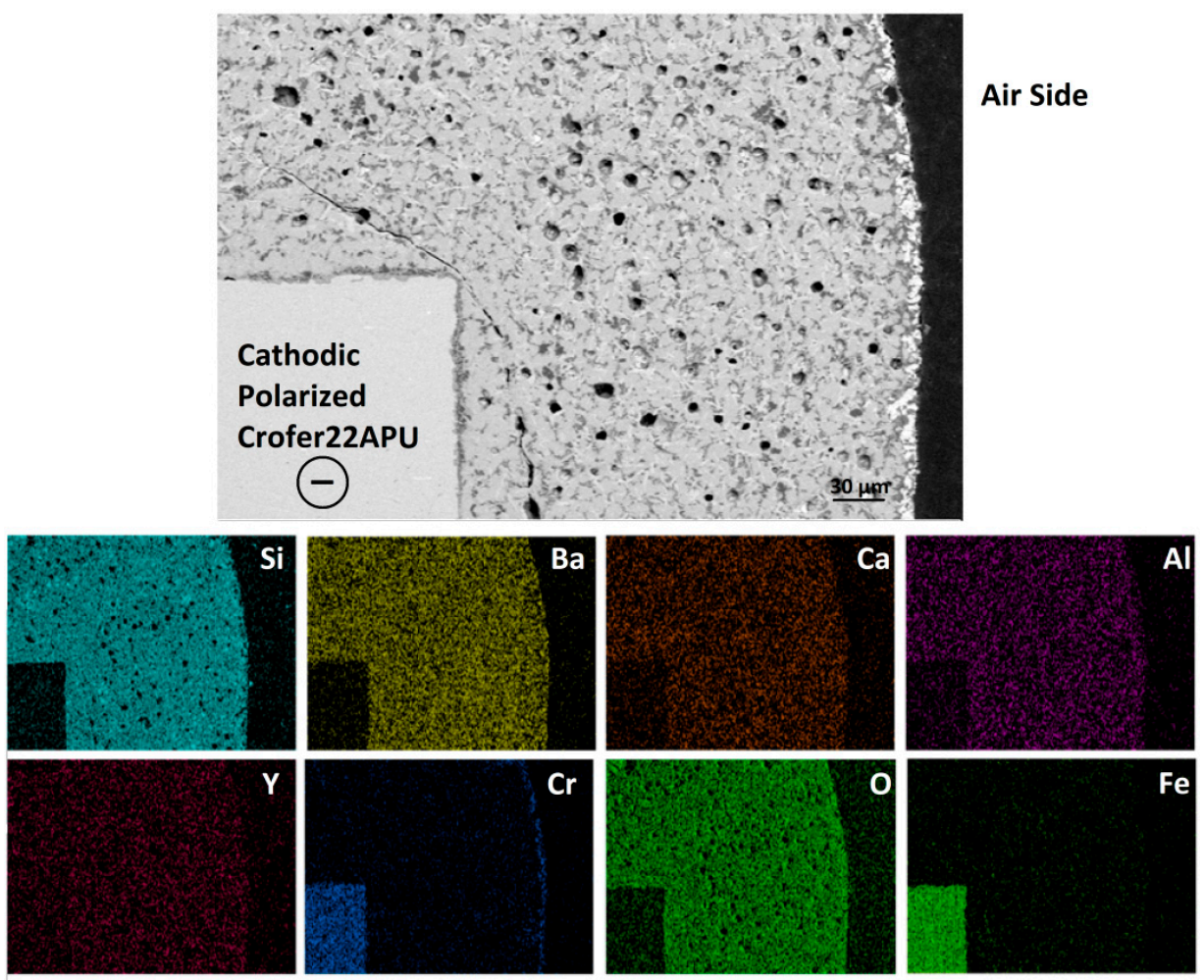

Figure 6. SEM-EDS post mortem analysis at cathodic polarized Crofer22APU/HJ28 glass-ceramic interface after the dual test, collected at air side.

The EDS analysis confirmed that there is no segregation of elements within the glass-ceramic, nor at Crofer22APU/glass-ceramic interface.

Figure 7 corresponds to the SEM-EDS analysis at the anodic polarized Crofer22APU/HJ28 glass-ceramic interface collected at the air side. The EDS analysis and uniform microstructure confirmed that under the applied voltage of $1.6 \mathrm{~V}$ no migration of ions has been observed toward any specific polarity. Similar to cathodic polarized Crofer22APU, a thin layer $(-10 \mu \mathrm{m})$ of $\mathrm{BaCrO}_{4} \mathrm{can}_{\text {be }}$ seen in Figure 7 and is localized only along the air side. A suitable $\mathrm{SiO}_{2} /\left(\mathrm{SiO}_{2}+\mathrm{BaO}\right)$ in $\mathrm{HJ} 28$ glass system not only resulted in the formation of the desired crystalline phase, but also minimal $\mathrm{BaCrO}_{4}$ formation. Nevertheless, Figure 7 shows a negligible concentration of Si rich phases between the chromates and the Crofer22APU substrate, formed because of the fact that the formation of $\mathrm{BaCrO}_{4}$ slightly imbalanced $\mathrm{SiO}_{2} / \mathrm{BaO}$ thus, resulting in locally higher $\mathrm{SiO}_{2}$ content. 

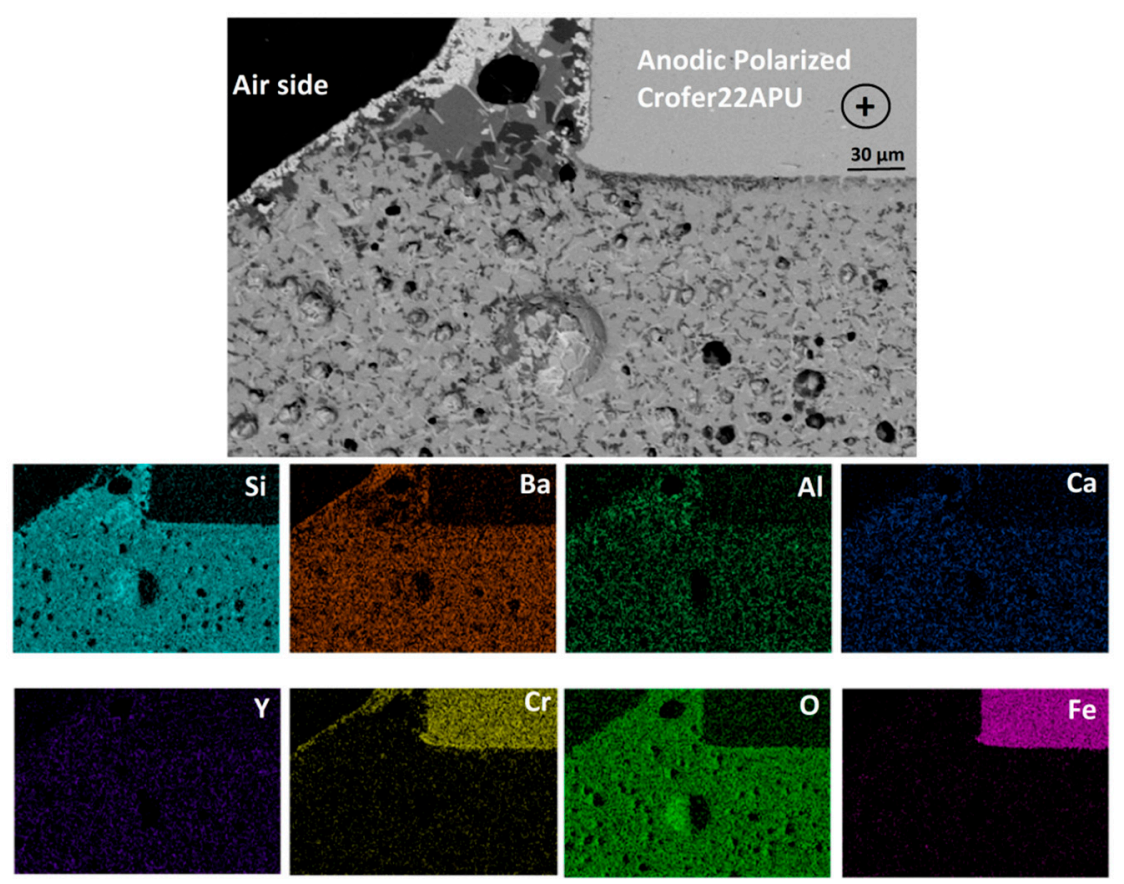

Figure 7. SEM-EDS post mortem analysis at anodic polarized Crofer22APU/HJ28 glass-ceramic interface after the dual test, collected at air side.

In a previous study, Sabato et al. [21] observed the formation of detrimental reaction between an alkali-containing glass-ceramic and Crofer22APU in similar operating conditions (dual atmosphere, $800{ }^{\circ} \mathrm{C}$ under applied voltage). This study highlighted the strong importance of the region exposed to air and the role played by the applied voltage in the presence of alkali metal oxide in the glass. These elements can react with $\mathrm{Cr}$ leading to degradation of the integrity of the sealant and formation of $\mathrm{Cr}_{2} \mathrm{O}_{3}$ bridges with consequent reduction in the resistivity. The present study did not detect any evidence of a similar reaction owing to the absence of alkali metal oxides. The sealant appears to be intact and no evidence of conductive "bridges" have been detected by SEM. The resistivity is also stable during all the measurement without noticeably decreasing.

Figure 8 shows the SEM post mortem analyses carried out at cathodic and anodic polarized Crofer22APU/glass-ceramic interface, on the fuel side. Likewise on air side, the HJ28 glass-ceramic seems to be strongly bonded to both the Crofer22APU plates having opposite polarity. No cracks were found within the HJ28 glass-ceramic nor at Crofer22APU/HJ28 glass-ceramic interface. The strong and crack-free interface also confirmed that the HJ28-glass-ceramic is stable under the applied thermal cycles. Moreover, the microstructure and level of closed porosity at the fuel side is also similar to that of the air side. 

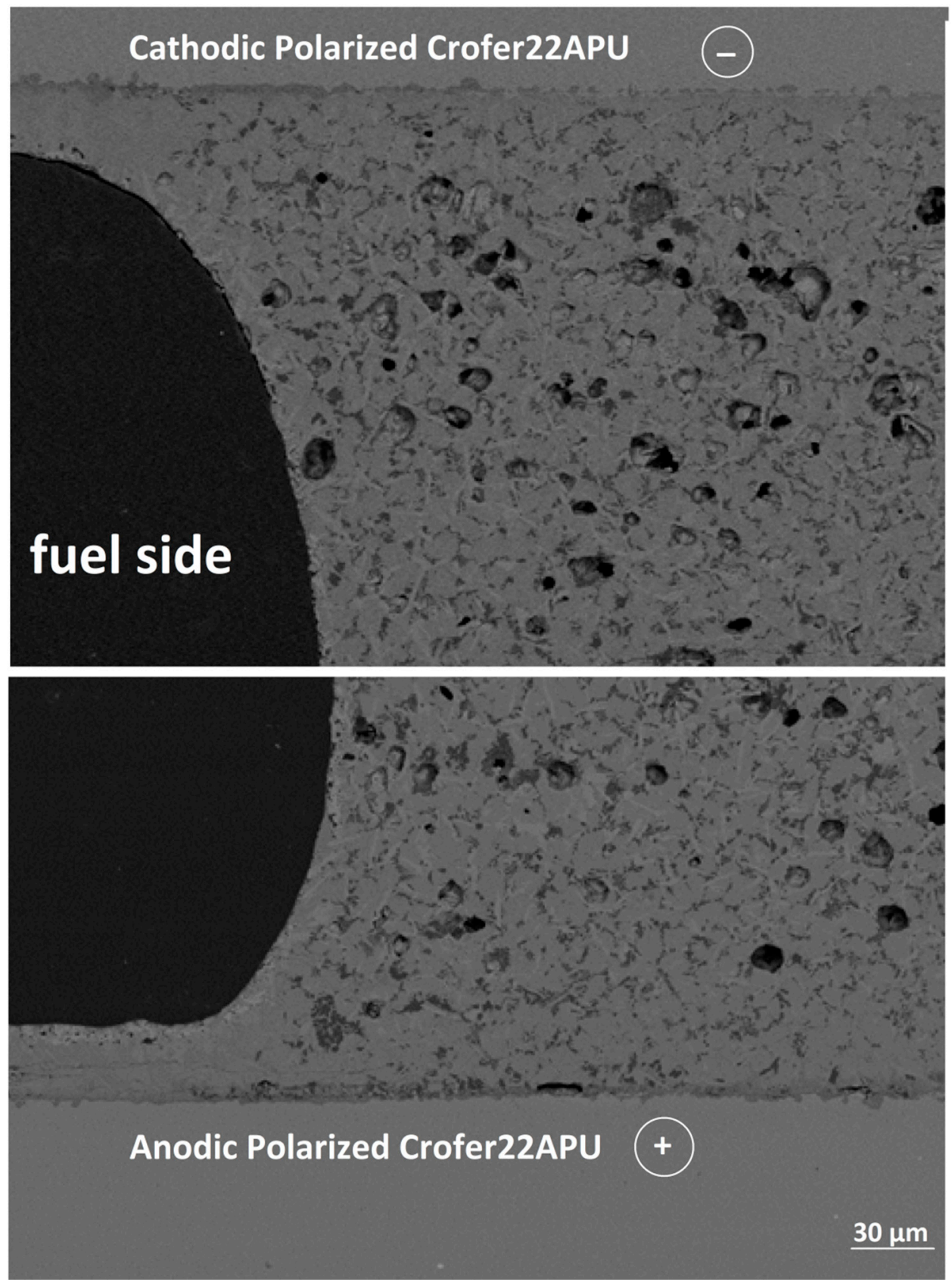

Figure 8. SEM-EDS post mortem analysis at cathodic and anodic polarized Crofer22APU/HJ28 glass-ceramic interface after the dual test, collected at fuel side.

\section{Conclusions}

The Ba-based glass system (HJ28) has been designed and tested for SOEC applications having a working temperature of $850^{\circ} \mathrm{C}$. The HJ28 glass-ceramic showed suitable CTE and excellent compatibility with Crofer22APU interconnect and 3YSZ electrolyte. The right sequence of crystallization and sintering processes led to the formation of dense sealant. The electrical resistivity of $10^{6}-10^{7} \Omega \mathrm{cm}$ was measured for Crofer22APU/HJ28 glass-ceramic/Crofer22APU joint, as measured for $2000 \mathrm{~h}$, at $850{ }^{\circ} \mathrm{C}$ and in simultaneously applied oxidizing and reducing atmospheres. Three full thermal cycles were also applied during the test at $500 \mathrm{~h}$. The SEM-EDS post mortem analysis confirmed the presence of strong bonding between the Crofer22APU substrate and HJ28 glass-ceramic, subjected to long-term resistivity test and thermal cycles. A very thin layer $(>10 \mu \mathrm{m})$ of $\mathrm{BaCrO}_{4}$ was observed along 
Crofer22APU/glass-ceramic/air 3-phase boundary, while no evidence of $\mathrm{BaCrO}_{4}$ propagation were found along Crofer22APU/glass-ceramic interface.

Owning to excellent thermal and thermo-mechanical properties, high electrical resistivity, and chemical stability, $\mathrm{HJ} 28$ glass-ceramic is a promising candidate to act as a reliable sealant for long-term SOEC conditions.

Author Contributions: H.J. gave the main idea regarding glass composition and wrote the manuscript. A.G.S. conducted the thermal and SEM analysis. M.M. and D.F. performed the electrical resistivity analysis in dual atmosphere. M.S. and K.H. helped in preparing the manuscript. C.W. and F.S. supervised the whole work and helped in interpretation of data. All authors have read and agreed to the published version of the manuscript.

Funding: This research received no external funding.

Conflicts of Interest: The authors declare no conflict of interest.

\section{References}

1. Pandiyan, A.; Uthayakumar, A.; Subrayan, R.; Cha, S.W.; Krishna Moorthy, S.B. Review of solid oxide electrolysis cells: A clean energy strategy for hydrogen generation. Nanomater. Energy 2019, 8, 2-22. [CrossRef]

2. Posdziech, O.; Schwarze, K.; Brabandt, J. Efficient hydrogen production for industry and electricity storage via high-temperature electrolysis. Int. J. Hydrog. Energy 2019, 44, 19089-19101. [CrossRef]

3. Kazempoor, P.; Braun, R.J. Hydrogen and synthetic fuel production using high temperature solid oxide electrolysis cells (SOECs). Int. J. Hydrog. Energy 2015, 40, 3599-3612. [CrossRef]

4. Yan, J.; Chen, H.; Dogdibegovic, E.; Stevenson, J.W.; Cheng, M.; Zhou, X.D. High-efficiency intermediate temperature solid oxide electrolyzer cells for the conversion of carbon dioxide to fuels. J. Power Sources 2014, 252, 79-84. [CrossRef]

5. Grigoriev, S.A.; Fateev, V.N.; Bessarabov, D.G.; Millet, P. Current status, research trends, and challenges in water electrolysis science and technology. Int. J. Hydrog. Energy 2020. [CrossRef]

6. Kothiyal, G.P.; Kothiyal, G.P.; Goswami, M.; Tiwari, B.; Sharma, K.; Ananthanarayanan, A.; Montagne, L. Some recent studies on glass/glass-ceramics for use as sealants with special emphasis for high temperature applications. J. Adv. Ceram. 2012, 1, 110-129. [CrossRef]

7. Fergus, J.W. Sealants for solid oxide fuel cells. J. Power Sources 2005, 147, 46-57. [CrossRef]

8. Javed,H.; Sabato, A.G.; Herbrig, K.; Ferrero, D.; Walter, C.; Salvo, M.; Smeacetto, F. Design and characterization of novel glass-ceramic sealants for solid oxide electrolysis cell (SOEC) applications. Int. J. Appl. Ceram. Technol. 2018, 15, 999-1010. [CrossRef]

9. Javed, H.; Sabato, A.G.; Dlouhy, I.; Halasova, M.; Bernardo, E.; Salvo, M.; Herbrig, K.; Walter, C.; Smeacetto, F. Shear Performance at Room and High Temperatures of Glass-Ceramic Sealants for Solid Oxide Electrolysis Cell Technology. Materials 2019, 12, 298. [CrossRef]

10. Khedim, H.; Nonnet, H.; Méar, F.O. Development and characterization of glass-ceramic sealants in the $\left(\mathrm{CaO}-\mathrm{Al}_{2} \mathrm{O}_{3}-\mathrm{SiO}_{2}-\mathrm{B}_{2} \mathrm{O}_{3}\right)$ system for Solid Oxide Electrolyzer Cells. J. Power Sources 2012, 216, 227-236. [CrossRef]

11. Ghosh, S.; Das Sharma, A.; Kundu, P.; Basu, R.N. Glass-ceramic sealants for planar IT-SOFC: A bilayered approach for joining electrolyte and metallic interconnect. J. Electrochem. Soc. 2008, 155, B473-B478. [CrossRef]

12. Fakouri Hasanabadi, M.; Faghihi-Sani, M.A.; Kokabi, A.H.; Groß-Barsnick, S.M.; Malzbender, J. Room- and high-temperature flexural strength of a stable solid oxide fuel/electrolysis cell sealing material. Ceram. Int. 2019, 45, 733-739. [CrossRef]

13. Rost, A.; Schilm, J.; Kusnezoff, M.; Michaelis, A. Degradation of sealing glasses under electrical load. Eur. Fuel Cell Forum 2010, 80, 1-12.

14. Tulyaganov, D.U.; Reddy, A.A.; Kharton, V.V.; Ferreira, J.M.F. Aluminosilicate-based sealants for SOFCs and other electrochemical applications - A brief review. J. Power Sources 2013, 242, 486-502. [CrossRef]

15. Ferrero, D.; Lanzini, A.; Leone, P.; Santarelli, M. Dynamic reversible SOC applications: Performance and Durability with simulated load/demand profiles. In Proceedings of the 11th European SOFC and SOE Forum 2014, Lucerne, Switzerland, 1-4 July 2014; Chapter 17, Session B14. pp. 60-67. 
16. Elsayed, H.; Javed, H.; Sabato, A.G.; Smeacetto, F.; Bernardo, E. Novel Glass-ceramic SOFC Sealants from Glass Powders and a Reactive Silicone Binder. J. Eur. Ceram. Soc. 2018, 38, 4245-4251. [CrossRef]

17. Smeacetto, F.; Salvo, M.; Santarelli, M.; Leone, P.; Ortigoza-Villalba, G.A.; Lanzini, A.; Ajitdoss, L.C.; Ferrarisa, M. Performance of a glass-ceramic sealant in a SOFC short stack. Int. J. Hydrog. Energy 2013, 38, 588-596. [CrossRef]

18. Sabato, A.G.; Salvo, M.; Santarelli, M.; Leone, P.; Ortigoza-Villalba, G.A.; Lanzini, A.; Ajitdoss, L.C.; Ferraris, M. Glass-ceramic sealant for solid oxide fuel cells application: Characterization and performance in dual atmosphere. J. Power Sources 2016, 328, 262-270. [CrossRef]

19. Smeacetto, F.; Salvo, M.; Leone, P.; Santarelli, M.; Ferraris, M. Performance and testing of joined Crofer22APU-glass-ceramic sealant-anode supported cell in SOFC relevant conditions. Mater. Lett. 2011, 65, 1048-1052. [CrossRef]

20. Reddy, A.A.; Tulyaganov, D.U.; Goel, A.; Pascual, M.J.; Kharton, V.V.; Tsipis, E.V.; Ferreira, J.M. Diopside-Mg orthosilicate and diopside-Ba disilicate glass-ceramics for sealing applications in SOFC: Sintering and chemical interactions studies. Int. J. Hydrog. Energy 2012, 37, 12528-12539. [CrossRef]

21. Sabato, A.G.; Rost, A.; Schilm, J.; Kusnezoff, M.; Salvo, M.; Chrysanthou, A.; Smeacetto, F. Effect of electric load and dual atmosphere on the properties of an alkali containing diopside-based glass sealant for solid oxide cells. J. Power Sources 2019, 415, 15-24. [CrossRef]

22. Chou, Y.S.; Stevenson, J.W.; Choi, J.P. Alkali Effect on the Electrical Stability of a Solid Oxide Fuel Cell Sealing Glass. J. Electrochem. Soc. 2010, 157, B348-B353. [CrossRef]

23. Arora, A.; Singh, K.; Pandey, O.P. Thermal, structural and crystallization kinetics of $\mathrm{SiO}_{2}-\mathrm{BaO}-\mathrm{ZnO}-$ $\mathrm{B}_{2} \mathrm{O}_{3}-\mathrm{Al}_{2} \mathrm{O}_{3}$ glass samples as a sealant for SOFC. Int. J. Hydrog. Energy 2011, 36, 14948-14955. [CrossRef]

24. Lin, S.E.; Cheng, Y.R.; Wei, W.C.J. BaO- $\mathrm{B}_{2} \mathrm{O}_{3}-\mathrm{SiO}_{2}-\mathrm{Al}_{2} \mathrm{O}_{3}$ sealing glass for intermediate temperature solid oxide fuel cell. J.Non Cryst. Solids 2012, 358, 174-181. [CrossRef]

25. Laorodphan, N.; Ayawanna, J. BaO- $-\mathrm{Al}_{2} \mathrm{O}_{3}-\mathrm{SiO}_{2}-\mathrm{B}_{2} \mathrm{O}_{3}$ Glass-Ceramic SOFCs Sealant: Effect of ZnO Additive. Key Eng. Mater. 2017, 751, 455-460. [CrossRef]

26. Ferraris, M.; De la Pierre, S.; Sabato, A.G.; Smeacetto, F.; Javed, H.; Walter, C.; Malzbender, J. Torsional shear strength behavior of advanced glass-ceramic sealants for SOFC/SOEC applications. J. Eur. Ceram. Soc. 2020, 40, 4067-4075. [CrossRef]

27. Lee, H.; Kim, U.S.; Kim, S.D.; Woo, S.K.; Chung, W.J. $\mathrm{SiO}_{2}-\mathrm{B}_{2} \mathrm{O}_{3}-\mathrm{BaO}-\mathrm{WO}_{3}$ glasses with varying $\mathrm{Al}_{2} \mathrm{O}_{3}$ content as a sealing material for reversible solid oxide fuel cells. Ceram. Int. 2020, 46, 18256-18261. [CrossRef]

28. Pascual, M.J.; Guillet, A.; Durán, A. Optimization of glass-ceramic sealant compositions in the system $\mathrm{MgO}-\mathrm{BaO}-\mathrm{SiO}_{2}$ for solid oxide fuel cells (SOFC). J. Power Sources 2007, 169, 40-46. [CrossRef]

29. Peng, L.; Zhu, Q. Thermal cycle stability of $\mathrm{BaO}-\mathrm{B}_{2} \mathrm{O}_{3}-\mathrm{SiO}_{2}$ sealing glass. J. Power Sources 2009, 194, 880-885. [CrossRef]

30. Ghosh, S.; Das Sharma, A.; Kundu, P.; Mahanty, S.; Basu, R.N. Development and characterizations of $\mathrm{BaO}-\mathrm{CaO}-\mathrm{Al}_{2} \mathrm{O}_{3}-\mathrm{SiO}_{2}$ glass-ceramic sealants for intermediate temperature solid oxide fuel cell application. J. Non Cryst. Solids 2008, 354, 4081-4088. [CrossRef]

31. Schilm, J.; Rost, A.; Kusnezoff, M.; Megel, S.; Michaelis, A. Glass ceramics sealants for SOFC interconnects based on a high chromium sinter alloy. I. J. Appl. Ceram. Technol. 2018, 15, 239-254. [CrossRef]

32. Zhang, R.; Taskinen, P. Experimental investigation of liquidus and phase stability in the $\mathrm{BaO}-\mathrm{SiO}_{2}$ binary system. J. Alloy. Compd. 2016, 657, 770-776. [CrossRef]

33. Kerstan, M.; Rüssel, C. Barium silicates as high thermal expansion seals for solid oxide fuel cells studied by high-temperature X-ray diffraction (HT-XRD). J. Power Sources 2011, 196, 7578-7584. [CrossRef]

34. Mahapatra, M.K.; Lu, K. Seal glass for solid oxide fuel cells. J. Power Sources 2010, 195, 7129-7139. [CrossRef]

35. Kim, S.J.; Kim, K.J.; Choi, G.M. A novel solid oxide electrolysis cell (SOEC) to separate anodic from cathodic polarization under high electrolysis current. Int. J. Hydrog. Energy 2013, 38, 20-28. [CrossRef]

36. Kerstan, M.; Mueller, M.; Ruessel, C. Binary, ternary and quaternary silicates of $\mathrm{CaO}, \mathrm{BaO}$ and $\mathrm{ZnO}$ in high thermal expansion seals for solid oxide fuel cells studied by high-temperature X-ray diffraction (HT-XRD). Mater. Res. Bull. 2011, 46, 2456-2463. [CrossRef]

(C) 2020 by the authors. Licensee MDPI, Basel, Switzerland. This article is an open access article distributed under the terms and conditions of the Creative Commons Attribution (CC BY) license (http://creativecommons.org/licenses/by/4.0/). 